\title{
Community-based tourism development viewed from economic, social culture and environment aspects in mandeh's integrated marine tourism area
}

\author{
Zefnihan $^{1}$ and Zikri Alhadi ${ }^{1, *}$ \\ ${ }^{1}$ Padang State University, Indonesia
}

\begin{abstract}
Development of community-based tourism became the forerunner of its formation a tourist village that has been increasingly accepted in most developing countries as a strategy against poverty reduction. In the tourism development should pay attention to the economic, social and cultural aspects as well as the environment. West Sumatera Provincial government is actively developing the tourism sector including Mandeh's tourism area. One of the reasons why this area become any parties concern is because this place has great potential in social, economic, cultural and environmental. Mandeh Tourism Area is not only having a beautiful scenery but many activities related to the potential that is related to each other. Therefore, this article aims to describe the development of sustainable tourism and a positive impact for the welfare of the community.
\end{abstract}

\section{Introduction}

Mandeh tourism area is located in the west of West Sumatera Province and becomes part of Pesisir Selatan Regency to be exact at Koto XI district. Mandeh is located the primary artery that connects Padang with Bengkulu Province or referred to as the West Cross at \pm $60 \mathrm{~km}$ to the Tarusan's intersection. From the intersection turn to the south, after $2 \mathrm{Km}$ there is a Tjunction where the North way will lead to the Carocok and Ampang Pulai in the South. The Mandeh is $1.5 \mathrm{~km}$ from the T-junction. Another way to reach Mandeh is by using sea transportation from Padang City. Mandeh, as the new tourist destination which newly developed since 2014, is expected to become a leading destination in West Sumatra and International. From the Mandeh's tourist data during the last three years is increasing. There is no data in 2014 , in 2015 it reached 25,000 tourists and in 2016 reached 60,000 of tourism. Most tourists are from Indonesia besides overseas tourists. The increasing of the tourists is not followed by the readiness of supporting infrastructure and public preparedness in provide tourists' services.

Mandeh is not well known with the scenery also other activities that can be done there. Mandeh has several peaks that can see the beach from the top, besides having family tourism areas, exclusive area development for investment, cable car rides, special interest tours, and conservation, and the tourist can do sailing at the beach. Based on the tremendous potential, the planning and development should be well prepared and sustainable in order to get benefit sustainably from this region. The development of Mandeh area is essentially a form of space and source utilization natural resources for the national interest for broad public services, improving the welfare of local communities, and environmental conservation. Mandeh's development is characterized by local and community-based features, by increasing participation and expanding the rides and opportunities for people in working and investing. In the development this area it is important to identify, design and package the natural condition, local wisdom, customs, culinary and local special products, and hereditary cultures that will serve as a comparative advantage of community-based tourism that can meet the expectations of local and international tourists. In addition, identify the economic implications, sociocultural implications, and possible environmental implications in the future is also necessary.

According to Murphy [1], [2] in [3] the development of tourism should be a community-based activity, with the main factor that the resources and uniqueness of the local community are both physical and non-physical (traditions and cultures) attached to the community must be a major point of tourism. [3] stated that to make tourism development work well and well managed, the most fundamental thing to do is how to facilitate the wide involvement of local communities in the development process and maximize the value of social and economic benefits of tourism activities for local community's. Sustainable development aims to improve the welfare of society, to fulfill human needs and aspirations.

Sustainable development aimed to find the equity of development from generation to generation. The development of sustainable development concepts should consider the social and cultural needs, disseminating values that create different standards of

* Corresponding author: zikrialhadi@fis.unp.ac.id 
consumption within the limits of environmental capabilities, and everyone is able to aspire to them naturally.

Meanwhile, many scientists who acknowledge that the mass tourism industry has an impact on the inconvenience of enjoying the scenery and the saturation in enjoying the accommodation which is considered exclusive and luxurious, so there are special interest tourism activities such as marine tourism, religious tourism, and ecotourism, which each has its own motives in enjoying it $[4,5]$. Exclusive tourism development one of its aims is to achieve environmentally-based tourism as part of sustainable development commitment.

Sustainable tourism is a rapidly growing tourism sector, including accretion of accommodation capacity, local population, and environment, where the development of tourism and new investments in the tourism sector should not bring adverse impacts and can blend with the environment if the positive impact is maximizing and minimize the negative impact. Thus sustainable tourism development is closely linked to ensuring that the natural, social and cultural resources utilized for tourism development in this generation can be enjoyed for future generations.

The studies related to the community-based tourism has done by several researchers. Community-Based Tourism (CBT) is an alternative form of tourism developed based on negotiation and participation for stakeholder purposes interests [6]. CBT is generally associated with local community involvement in the planning, development, management, and benefits of tourism [5,7-14]. As stated by [15] lack of knowledge is the main barrier of society to participate effectively in the development of rural tourism. The concept of CBT has emerged in response to the negative impacts of mass tourism that occurred during the early stages of tourism development; especially against local people [1].

In addition, the main obstacles that inhibit rural communities to actively participate and get benefit from tourism development are due to the development of human resources. Most rural communities are uneducated compared to those living in urban areas. Thus, they have limited knowledge, skills and resources to engage in the tourism development and management. Meanwhile, [16] Studies by experts have explained that many rural have a various livelihood as a result of the tourism development [17,18]

Sustainable natural and environmental conditions are assets that must be maintained to maintain tourism sustainability. Local people act as subjects, where cultural elements play an important role. Their motivation and participation are the driving factors that can keep the value of tourism uniqueness. So that can be used as a local wisdom that is the foundation of sustainable development in the tourist village is the participation of the community [19]

\section{Methodology}

The approach used in this research is a qualitative research approach with descriptive form. Data collection techniques that are by using literature study, observation of the location of the study and conduct unstructured interviews with some informants in the tourist area of Mandeh. The informants were the officials of the Department of Tourism, Tourism Management, Group Aware Tour, the community around the sights and the visitors. Meanwhile, to test the validity of data that has been collected by using the triangulation method.

To compile this article the author also uses relevant references on the development of community-based tourism in terms of economic, socio-cultural and environmental aspects in the form of literary studies. In addition, observations were also made to discover the phenomenon of sustainable tourism in the Integrated Tourism Area of Mandeh.

\section{Discussion}

\subsection{Community based tourism development viewed from economic aspects.}

The development of the Mandeh area tourism which is characterized by local uniqueness and community-based features is to increase the participation and expand the spaces and opportunities for the community in working, investing. The livelihood of the community was originally a traditional fisherman who conducted fishing and cultivation around the coast of Mandeh. By developing the tourism sector where the increase in visits to the Mandeh in principle has not provided significant benefits to the community. Massive tourism and local tourist visits have not been economically beneficial in raising community incomes, but have opened many livelihood diversifications around the Mandeh.

Types of business that has begun such as tourist boat business services, souvenirs store, small traders, homestay, restaurants, traditional art business, and others. The tourism business services begin to develop in local and traditional scale. In its development began to emerge the desire to increase the business from various limitations of individuals. The steps taken are initiated by the activists in cooperation with the government and made a community - based tourism groups by the entrepreneurs. In the early stages of group formation aimed to optimize the involvement and participation of the community in the development of tourism that cannot be dammed again, especially with the promotion of social media that does not require large funds but broad-impact.

In addition, the involvement of local communities becomes very important as tourism develops and local communities are a form of mutually influencing and mutually beneficial relationships. Tourism groups that have been formed include a group of ecotourism boats, culinary eco group, eco-tourism group of traditional arts and homestay group. With these tourism community groups, the community's position in tourism development and as a beneficiary of the development of tourism is more important and accountable than its existence on individuals. 
The problems faced in the role and involvement of ecotourism groups which also happened in another place is the local human resources quality that is essentially geographically and economically left behind. The efforts of activists and the government in order to improve human resources by conducting training which is the benefits significantly does not see. The training models are conducted in a variety such as face-to-face, roleplaying, and even try to introduce tourism groups with expert tour groups which have to get the benefit as ecotourism both economically and policymaker.

By doing this effort, a few groups of communities feel the benefit of improving their knowledge and skill in tourism development.it can be seen from the products such quality of homestay, culinary standardization, boat tour service, and others. By increasing the quality, the communities' income will directly increase. By learning from their experience and involvement in tourism management, the community feels the ownership and economic benefit from tourism. This condition will certainly have an impact on the development of a tourist village whose people have been positive towards the development of tourism and actively involved in preserving the existing tourism resources.

\subsection{Community based tourism development viewed from socio-cultural aspects}

Preserving local cultural values by fostering and expanding the local art and culture potential, community development to appreciate local culture, as well as the preservation of cultural heritage objects is important in a tourism village development. Traditional and cultural tourism assets in Mandeh area that can be appointed as tourism assets are shown in Table 1.

Table. 1. Traditional and cultural tourism assets in Mandeh

\begin{tabular}{|c|l|}
\hline \multirow{2}{*}{$\begin{array}{c}\text { Tourism } \\
\text { and } \\
\text { Cultural } \\
\begin{array}{c}\text { Assets of } \\
\text { Mandeh }\end{array}\end{array}$} & $\begin{array}{l}\text { Art tourism such as traditional music, } \\
\text { traditional dance, theatre, festival, and crafts }\end{array}$ \\
\cline { 2 - 2 } & $\begin{array}{l}\text { Traditional culinary such traditional } \\
\text { Mandehnese seafood }\end{array}$ \\
\cline { 2 - 2 } & $\begin{array}{l}\text { Customs and culture such as balimau, } \\
\text { bakauah, mamukek (fishing) and consensus }\end{array}$ \\
\cline { 2 - 3 } & The Architecture of Traditional-coastal house \\
\hline
\end{tabular}

The types of art that exist in Mandeh area are rabab (traditional violin), dendang pasisia (traditional song), and dances such as baruak dance and kain dance. Typical customs are found in the Mandeh area (a) consensus in Sungai Pinang, (b) Mamukek fishing) in Karam Island, Mandeh and Sungai Pinang. Other traditions such as various folk games such: randai, sikoci, rope skipping, canoeing, hide and seek, duku barrels beside that myth or legend story still lives in Mandeh Area. Based on the research has been identified more or less 50 pieces of folklore/legend on 5 nagari (sub-district) in Mandeh tourist area. The overall assets of tradition in the form of habits/customs and mythology can be an asset of cultural tourism that strengthens the character of Mandeh as a tourist area. While the typical culinary Mandeh can be promoted are Snails and Shrimp Coral, Randang Lokan, Rujak Nipah Fruit, Octopus Kalio, Lontong with banana curry, Kacung Uih, Coki and so on.

The variety of art and cultural attractions that flourish in Mandeh is a form of local wisdom that has been maintained since long time ago. Develop in accordance with the development of human civilization nowadays. This local wisdom has led to the occurrence of natural harmony and human being so, besides the beautiful scenery, Mandeh has a strong socio-cultural potential in their daily lives to fulfill needs.

Cultural values and local wisdom is in accordance with the times are also eroded by the development of technology and information. The phenomenon is quite interesting since the development of tourism in the last three years in the Mandeh area, harmonious life between nature and local wisdom owned by the community attract the tourists. This condition also makes the development of community-based tourism that has begun to grow, moving to explore and revive the values that have grown since long. Local wisdom through the cultural, artistic, and daily life of the people came alive to be able to have economic value in tourism development.

The community with its eco-group that seeks to stimulate and value these local wisdom values derives its economic value by making it a tour package so that with the development of this community-based tourism, local wisdom through the arts of culture and tradition becomes valuable rather than social but also from the economic side. Thus the people of Mandeh Regions through their social and cultural life and their local wisdom are in line with the development of tourism to get the various added value that is the preservation of cultural values and the increase of economic value.

\subsection{Community based tourism development viewed from environmental aspects}

Space utilization for tourism in Mandeh Area is a decision of determining the function of tourism for a unit of a region by considering the function of environmental protection for the region concerned. Tourism activities need to ensure the sustainability of environmental protection function and the sustainability of tourism activities in the future. Nature and environment are the main objects of the basic asset of tourism development of Mandeh, both as attractions and facilities that support tourism. Natural conditions and a sustainable environment are assets that must be maintained to sustain tourism. Rural communities act as subjects, where cultural elements play an important role. Their motivation and participation are the driving factors that can keep the value of tourism uniqueness.

Mandeh area has the extraordinary potential of natural beauty, both from the scenery and under water. Mangrove forests, coral reefs, underwater scenery, 
extraordinary landscapes, protected forests which potentially attract the tourists and can be educational tourism and conservation activities. A form of local wisdom in managing is done through community participation. In providing sustainable economic value to the natural potential, ecotourism group has a very important role to be a booster and engage the wider community to maintain sustainability. The forms of nature conservation in terms of characters are more static, where the protected and preserved objects are fixed and the activities undertaken are to maintain a sustainable environment. In the context of tourism development, this can be a major factor, especially if it relies heavily on nature tourism.

The community must actively participate in developing variations of tourism objects to be more interesting and get the value of uniqueness. Crosscountry travel, outbound, and stunt attractions are an alternative development. In addition, forest management can be a special attraction that has educational aspects so that tourists can learn directly about the concept of nature conservation conducted. Simple processing of forest products such as herbs, crafts, and traditional foods is developed to extend the tourist to stay longer because this activity can be packed into an attraction.

The form of environmental preservation, in terms of the character of the action more dynamic, where the object is preserved will always evolve in accordance with the development of nature tourism that occurred. The educational tourism is very important in order to lead the tourist to visit. A well-organized tourism area will attract tourists to visit. Communities should actively participate in recycling developing of their own industries. Integrated the recycling can be an alternative to packaging attractions, the concept of "one-stop industry" can be applied so that tourists can learn the production process from raw materials to ready-to-sell products followed by integrated environmental management. Thus, the development of tourism conducted by the community through ecotourism group in Mandeh Area has an impact on environmental conservation. With the principle of preserving the Mandeh areas are expected to attract the tourism will increase.

\section{Conclusion}

Nature and environment is a main object of the basic assets in tourism development, both as attractions and facilities that support tourism. The sustainable of Natural and environmental conditions are assets that must be maintained to maintain tourism sustainability. Local communities act as subjects, in which social and cultural elements play an important role in motivating and enhancing their participation in encouraging and maintaining the unique value of tourism.

Tourism is one of the sectors that the government relies on to gain foreign exchange and non-oil revenues. The role of tourism in the framework of national development is very large, such role in the form of or expand and create new jobs, reduce unemployment. In a new paradigm, the development of tourism based on the community requires a change of approach from the topdown approach that has been dominating the development process into a bottom up. This approach is very appropriate in supporting the community empowerment program and is the main thing to be done. A tourism development approach that places the community as an integral part of tourism products and the understanding that tourism products are a social engineering process of community- based development.

The development of community-based tourism became the forerunner of tourism that has been increasingly accepted in most developing countries as a strategy against poverty reduction. Tourism can diversify people's livelihoods with their development. With community-based tourism, communities are expected to optimize the role that tourism development will have an impact on economic development, sustainability of socio-cultural values and environmental sustainability.

\section{References}

1. Murphy, P.E. ( 1985), Tourism: A Community Approach, New York: Methuen

2. Dwyer, L., Forsyth, P., \& Dwyer, W. (2010). Tourism economics and policy (Vol. 3). Channel View Publications

3. Sunaryo (2013). Tourism Destination Development Policy: Concepts and Applications in Indonesia. Yogyakarta: Gava Media. 16

4. Kusworo, HA (2000) Development of Community-based Forest Edge Rural Tourism in Ecotourism Exploitation, Ecotourism Exploitation. Chafid Fandeli, ed. Faculty of Forestry. Yogyakarta: Gadjah Mada University

5. Suriani, N. E., \& Razak, M. N. (2011). Mapping of Ecotourism Potential in Baluran National Park. Research Journal of Tourism D3, FISIP, Airlangga, 24 (3) .19

6. Harun, H., Hassan, R., Razzaq, A., Rasid, A., \& Mustafa, M. Z. (2012). Building local capacities towards sustaining community-based tourism development (CBET): experience from Miso Walal Homestay, Kinabantangan Sabah, Malaysia.

7. Amati, C. (2013). "We all voted for it": experiences of participation in communitybased ecotourism from the foothills of $\mathrm{Mt}$ Kilimanjaro. Journal of Eastern African Studies, 7(4), 650-670

8. Hiwasaki, L. (2006). Community-based tourism: A pathway to sustainability for Japan's protected areas. Society and Natural Resources, 19(8), 675-692.

9. Matarrita-Cascante, D., Brennan, M. A., \& Luloff, A. E. (2010). Community agency and sustainable tourism development: The case of 
La Fortuna, Costa Rica. Journal of Sustainable Tourism, 18(6), 735-756.

10. Okazaki, E. (2008). A community-based tourism model: Its conception and use. Journal of sustainable tourism, 16(5), 511-529.12

11. Ruiz, E., Hernández, M., Coca, A., Cantero, P., \& Campo, A. D. (2008). Turismo comunitario en Ecuador. Comprendiendo el communitybased tourism desde la comunidad. Pasos. Revista de turismo y patrimonio cultural, 6(3).13

12. Stone, L. S., \& Stone, T. M. (2011). Community-based tourism enterprises: challenges and prospects for community participation; Khama Rhino Sanctuary Trust, Botswana. Journal of Sustainable Tourism, 19(1), 97-114.15

13. Timothy, D. J., \& Tosun, C. (2003). Arguments for community participation in the tourism development process. Journal of Tourism Studies, 14(2), 2.17

14. Ruiz-Ballesteros, E., \& Cáceres-Feria, R. (2016). Community-building and amenity migration in community-based tourism development. An approach from southwest Spain. Tourism Management, 54, 513-523.20

15. Moscardo, G. (2010). The Shaping Of The Tourist Experience. The importance of stories and themes. the tourism and leisure experience: Consumer and managerial perspectives, 43-58.

16. Prabhakaran, S., Nair, V., \& Ramachandran, S. (2014). Community participation in rural tourism: Towards a conceptual framework. Procedia-Social and Behavioral Sciences, 144, 290-295. 18

17. Briedenhann, J., \& Wickens, E. (2004). Tourism routes as a tool for the economic development of rural areas-vibrant hope or impossible dream?. Tourism Management, 25(1), 71-79.

18. Mair, H. (2006). Global restructuring and local responses: Investigating rural tourism policy in two Canadian communities. Current Issues in Tourism, 9 (1), 1-45.

19. Vitasurya, V. R. (2016). Local wisdom for sustainable development of rural tourism, the case on Kalibiru and Lopati Village, Province of Daerah Istimewa Yogyakarta. ProcediaSocial and Behavioral Sciences, 216, 97-108.21 